University of Nebraska - Lincoln

DigitalCommons@University of Nebraska - Lincoln

Publications, Agencies and Staff of the U.S.

Department of Commerce

U.S. Department of Commerce

2011

Using aerial photography to investigate evidence of feeding by bowhead whales

Julie A. Mocklin

NOAA, julie.mocklin@noaa.gov

David J. Rugh

NOAA

Sue E. Moore

NOAA

Robyn P. Angliss

Alaska Fisheries Science Center

Follow this and additional works at: https://digitalcommons.unl.edu/usdeptcommercepub

Part of the Environmental Sciences Commons

Mocklin, Julie A.; Rugh, David J.; Moore, Sue E.; and Angliss, Robyn P., "Using aerial photography to investigate evidence of feeding by bowhead whales" (2011). Publications, Agencies and Staff of the U.S. Department of Commerce. 292.

https://digitalcommons.unl.edu/usdeptcommercepub/292

This Article is brought to you for free and open access by the U.S. Department of Commerce at DigitalCommons@University of Nebraska - Lincoln. It has been accepted for inclusion in Publications, Agencies and Staff of the U.S. Department of Commerce by an authorized administrator of DigitalCommons@University of Nebraska - Lincoln. 
MARINE MAMMAL SCIENCE, $* *(*): * * * \_* * *(* * * 2011)$

2011 by the Society for Marine Mammalogy

Published 2011. This article is a US Government work and is in the public domain in the USA.

DOI: $10.1111 / \mathrm{j} .1748-7692.2011 .00518 . x$

\title{
Using aerial photography to investigate evidence of feeding by bowhead whales
}

\author{
Julie A. MOCKLIN \\ DAVID J. RugH \\ National Marine Mammal Laboratory, \\ Alaska Fisheries Science Center, \\ National Marine Fisheries Service, NOAA, \\ 7600 Sand Point Way NE, \\ Seattle, Washington 98115, U.S.A. \\ E-mail: julie.mocklin@noaa.gov \\ Sue E. MOORE \\ Office of Science and Technology-OERD2, \\ National Marine Fisheries Service, NOAA, \\ 7600 Sand Point Way NE, \\ Seattle, Washington 98115, U.S.A. \\ RoBYN P. ANGLISS \\ National Marine Mammal Laboratory, \\ Alaska Fisheries Science Center, \\ 7600 Sand Point Way NE, \\ Seattle, Washington 98115 , U.S.A.
}

\begin{abstract}
Aerial photographs were analyzed to investigate the feeding habits of the BeringChukchi-Beaufort (BCB) population of bowhead whales (Balaena mysticetus), particularly epibenthic feeding near Barrow, Alaska. Evidence of epibenthic feeding was based on mud visible on the dorsal surface of whales, resulting from feeding near the seafloor. Other cues used to assess feeding were an open mouth or the presence of feces in photographs. Over 3,600 photographs were analyzed including photos from surveys in spring and late summer and in both the western and eastern Beaufort Sea. Of all the photographs analyzed, $64 \%$ were scored as definitively muddy. In spring, ratios ranged from a low of $27 \%$ in 2003 to a high of $76 \%$ in 2004 . When all May sample sets off Barrow were combined (1985, 1986, 2003, 2004), there was a significant difference ( $t$-test, $P<0.004$ ) between the proportion of muddy juveniles to the proportion of muddy adults, with muddy adults being more common. The Barrow area was a commonly used feeding ground during migrations in both the spring ( $61 \%$ of the sample were feeding; $55 \%$ epibenthically) and autumn (99\% of the sample; $97 \%$ epibenthically). Bowheads both migrate and feed through areas where petroleum extraction is underway and anticipated; hence, exposure to oil after a spill is of considerable concern to Native communities and management agencies.
\end{abstract}


Key words: bowhead whale, Balaena mysticetus, aerial photography, feeding behavior, epibenthic feeding.

Bowhead whales (Balaena mysticetus) are circumpolar in distribution in the Northern Hemisphere (Moore and Reeves 1993). This study focuses exclusively on bowhead whales that occupy the Bering-Chukchi-Beaufort Seas, often referred to as the BCB stock. Aerial surveys to photograph these whales have been conducted intermittently during the past $30 \mathrm{yr}$. The utility of using these aerial photographs to identify individual whales has been well documented, and applications include mark-recapture abundance estimation (Rugh 1990, Da Silva et al. 2000, Schweder 2003, Koski et al. 2010), estimation of survival rates (Zeh et al. 2002), calving intervals (Miller et al. 1992, Rugh et al. 1992), and measurement of individual growth rates (Koski et al. 1992, 1993). BCB bowheads migrate in the spring from the northern Bering Sea, past Barrow, and into the eastern Beaufort Sea where they spend the summer feeding. In the autumn, they make the reverse migration back to the northern Bering Sea where they overwinter (Moore and Reeves 1993). Bowhead whales feed sporadically during both the spring and autumn migrations while en route to the feeding grounds, but feeding is traditionally believed to be more prevalent in the autumn than the spring (Lowry and Frost 1984, Carroll et al. 1987, Lowry et al. 2004). However, Lowry et al. (2004) were the first to report that feeding near Barrow in the spring is actually quite common, although the amount of food consumed appears to be lower in spring compared with autumn.

Bowhead whales exhibit three basic feeding strategies: surface feeding, watercolumn feeding, and bottom feeding (hereafter referred to as epibenthic feeding) (Würsig et al. 1989). Surface feeding can occasionally be captured photographically via observations of whales with open mouths or in echelon formation, but aerial images cannot document water-column feeding. On the other hand, we postulate that whales feeding epibenthically often become coated with mud on their dorsal surface, which is easily detectable in many photographs in the National Marine Mammal Laboratory (NMML) collection. The current research applies photo-analysis as a tool to study epibenthic feeding. Without aerial photography, it is easy to miss evidence of feeding while in flight, particularly when there is minimal circling. Although visual, in situ assessments of bowhead whale feeding strategies are available (Ljungblad et al. 1986, Würsig et al. 1989, Würsig and Clark 1993, Landino et al. 1994), no published research has focused on analyzing photographs for clues to feeding behavior.

Much of what is known about bowhead feeding comes from biological examination of stomach contents from animals killed in the subsistence hunt. Bowhead whales feed primarily on copepods and euphausiids, but also consume amphipods, mysids, fish, and other invertebrates (Lowry 1993, Lowry et al. 2004). Notably, although some studies have referred to epibenthic prey to mean epibenthic forms of mysids and amphipods (Hazard and Lowry 1984, Lowry 1993), the current study is presuming that bowheads are actually targeting epibenthic aggregations of copepods and euphausiids. There is evidence to support this presumption. Lowry (1993) stated that in 10 of 12 stomach samples containing pebbles, the dominant prey was copepods and euphausiids, and he suggested that this is likely indicative of whales feeding very near or on the seafloor. These prey were also dominant in the stomachs of most whales sampled in 2005-2006 (Moore et al. 2010). Additionally, it is well known that copepods and euphausiids undergo diel vertical migrations in the water column such that they are at the surface at night and near the seafloor during the day as a predator 
avoidance strategy (Fortier et al. 2001, Hays 2003). Laidre et al. (2007) attached time-depth-recorders on bowheads during the day off West Greenland and found most dives were targeting the bottom. The researchers also conducted water-column sampling for zooplankton and found that copepods were dense near the bottom, in concentrations that were several orders of magnitude greater than all other prey categories and at any other depth. The authors concluded that bowheads were likely targeting preascension stage epibenthic copepods. They also report that after retrieving dorsally mounted tags, some instruments had mud on them, suggesting recent contact with the bottom. Krutzikowsky and Mate (2000) presumed that the long deep dives made by some of the bowheads tagged in the eastern Beaufort Sea were targeting calanoid copepods in the water column or near the seafloor. Zooplankton that descend to deeper water in the summer tend to be larger and have a greater lipid content than those found in the upper column (Baumgartner et al. 2003, Hays 2003). Therefore, it may be advantageous for bowheads to target prey at depths in order to consume a more calorically dense meal. Simon et al. (2009) showed that bowheads ram filter feed continuously at depth during the typical U-shaped feeding dive of balaenids.

Würsig et al. (1989) and Lowry (1993) suggested that juvenile bowheads may feed epibenthically more often than adults, based on behavioral observations and stomach contents. Hazard and Lowry (1984) posited that, due to inexperience and shorter baleen, bottom feeding may be more practical for juvenile whales. With disproportionally smaller mouths, young whales may be more dependent than adults on prey concentrations near the seafloor. ${ }^{1}$

The motivation behind the photographic analyses conducted in this study was fourfold: first, to demonstrate that photographic analysis can be a useful tool to elucidate epibenthic feeding behavior; second, to investigate how common epibenthic feeding is; third, to corroborate evidence that feeding is common near Barrow; and fourth, to explore the demographics of bowheads using this feeding strategy.

There are important management implications regarding the feeding habits of BCB bowheads, as the whales are migrating and feeding in active and proposed areas of oil exploration and development, offshore of both Canada and Alaska. If a large proportion of the population is regularly muddied, then it behooves managers to research how oil spills may affect the substrate and consequently the whales that are exposed to it. This study also emphasizes the importance of areas where there is evidence of feeding, areas that had previously been presumed to be only migratory corridors. Understanding bowhead feeding ecology is imperative for the continued protection of this endangered species, especially in a warming and rapidly changing ecosystem.

\section{METHODS}

There are over 18,000 images in the photographic collection at NMML. Instead of systematically reviewing the entire collection, our study focused on years 1985, 1986, 2003, and 2004 (Table 1), which contained the largest and most consistent photographic samples in the Barrow area. In these years, the objective was to photographically capture a representative sample of the entire spring migration of bowhead whales in order to calculate abundance estimates of the stock (Zeh et al. 1993, Koski et al. 2010). These photographic surveys afforded an opportunity to compare the

\footnotetext{
${ }^{1}$ Personal communication from Craig George, North Slope Borough Department of Wildlife Management, PO Box 69, Barrow, AK 99723, January 2011.
} 
Table 1. Data sets used to examine the percent of the sampled aerial photographs of bowhead whales that showed evidence of feeding. Population estimates are from Zeh et al. (1993) and Koski et al. (2010). ${ }^{*}=2005$, 2006, and 2007 were not representative samples of the population, so no attempt to discern the percent of the population captured photographically was made for those years.

\begin{tabular}{lllccc}
\hline \hline Year & Month & \multicolumn{1}{c}{ Area } & $\begin{array}{c}\text { No. of } \\
\text { images } \\
\text { evaluated }\end{array}$ & $\begin{array}{c}\text { Population } \\
\text { estimate }(95 \% \\
\text { confidence interval) }\end{array}$ & $\begin{array}{c}\text { Population } \\
\text { evaluated }(\%)\end{array}$ \\
\hline 1985 & Aug./Sept. & E. Beaufort Sea & 162 & $7,800(5,700-10,600)$ & 2 \\
1985 & May & Barrow & 440 & $7,800(5,700-10,600)$ & 6 \\
1986 & May & Barrow & 396 & $7,800(5,700-10,600)$ & 5 \\
2003 & May & Barrow & 929 & $12,631(7,900-19,700)$ & 7 \\
2004 & May & Barrow & 706 & $12,631(7,900-19,700)$ & 6 \\
2005 & September & Barrow & 101 & $*$ & $*$ \\
2006 & September & Barrow & 566 & $*$ & $*$ \\
2007 & August & Barrow & 349 & & $*$ \\
& & & Total $=3,649$ & & $*$ \\
\hline
\end{tabular}

prevalence of epibenthic feeding in spring near Barrow across $20 \mathrm{yr}$. Our samples were limited further by looking at images taken only in May between $152^{\circ}$ and $157^{\circ}$ longitude, a period and area that was most consistently sampled. In addition to these four sample years, four other data sets were included to examine more variables. A sample set was included from the eastern Beaufort Sea in August/September 1985 to compare epibenthic feeding in two areas (western vs. eastern Beaufort Sea) and two seasons (spring vs. late summer) within $1 \mathrm{yr}$. Also, images were evaluated from August/September 2005, 2006, and 2007 near Barrow to further examine the relationship between spring and late summer percentages of feeding whales.

\section{Scoring Photographs}

The photographic evaluations consisted of determining the presence/absence of mud in each of four zones on the body (rostrum, cheeks, back, and flukes), and the associated confidence for each decision (see Fig. 1 for an example of whales with

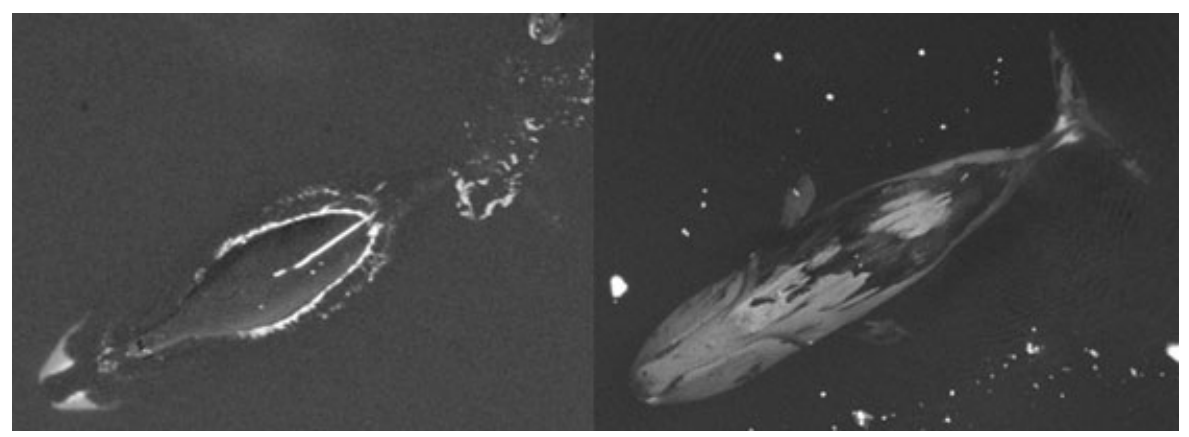

Figure 1. Examples of bowhead whales with no mud on the body (left) and covered in mud (right). 
and without mud present). There were three possible levels of confidence to assign: definitely ( $>90 \%$ sure), probably ( $>70 \%$ sure), or unsure ( $<70 \%$ sure). Additionally, we scored for the presence of an open mouth visible in the photograph (not open, slightly open, wide open, or indeterminable) and the associated confidence of that decision, and for the presence of a mud plume near the whale as well. Finally, we reviewed all of the scores in the individual zones to determine whether the whale in the image was feeding (and what the cue was). This decision was restricted to reflect that the evidence had been scored with at least $70 \%$ confidence (i.e., we did not make decisions based on evidence that was "unsure"). For a whale to be classified as feeding, as evidenced by mud, it meant that we were "probably" or "definitely" sure there was mud present in at least one of the zones on the body. Prior to conducting these photographic evaluations, we created tests of the scoring system to ensure that our definitions were teachable and repeatable and agreement was high enough to justify one person analyzing all of the photographs.

\section{Lengths}

In order to compare the proportions of muddy juveniles to muddy adults, length analysis was limited to images with photogrammetrically calculated lengths. The following whale lengths were considered to represent certain age classes based on published data of calving, growth rates, and photogrammetric measurements (Koski et al. 1993, Angliss et al. 1995): calves $\leq 6 \mathrm{~m}$, juveniles $>6 \mathrm{~m}$ and $<13 \mathrm{~m}$, and adults $\geq 13 \mathrm{~m}$.

We then excluded from analyses all calves and any oblique images $(n=5)$ with lengths between $11.5 \mathrm{~m}$ and $12.9 \mathrm{~m}$ since oblique measurements are less accurate, and the potential error involved could mean the difference between assigning a whale the status of juvenile $v s$. adult within those zones of overlap. The available sample size was then reduced to 2,322 images. An empirical logistic transform for binary data (Cox and Snell 1989) was used to transform the data for comparing proportions, and then a series of pairwise $t$-tests were used to compare the proportions of juvenile to adult muddy whales and to compare year-to-year proportions of muddy whales. Only photos from 2005, 2006, and 2007 (summer near Barrow) were excluded from age class analyses because they were not representative of the full population, so separating them by age class was not warranted.

\section{Flow Tank Tests}

To examine how long it might have been between when a whale had a bout of epibenthic feeding and when a photograph was taken of the whale with mud on its back, a series of tests was conducted to examine the rate that mud flushes off bowhead whale skin. A sample of bowhead skin was glued to fit a piece of plastic sheeting, and a grid was drawn on the skin with a silver permanent marker for a visual aid in assessing mud dissipation. The plastic sheeting filled the width of the flow tank, which allowed the skin to sit flush in the bottom of the tank, representing the broad head or back of a bowhead whale (Fig. 2A-C). The flow tank was small (overall length $2.4 \mathrm{~m}$; working section was $0.15 \mathrm{~m} \times 0.15 \mathrm{~m} \times 0.57 \mathrm{~m}$, width $\times$ height $\times$ length), so it was deemed inappropriate to try to add any curvature to the skin (since the size of our sample would effectively be flat on a whale). 


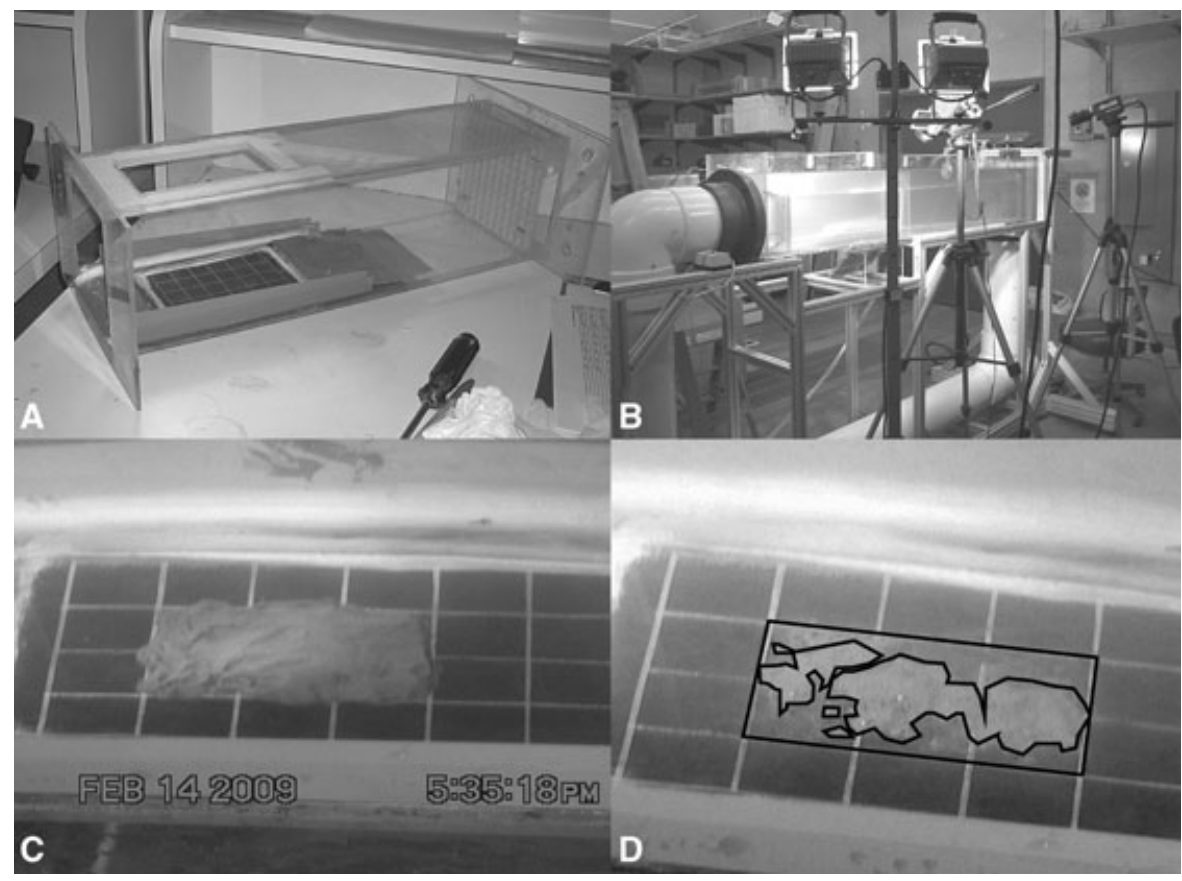

Figure 2. (A) Bowhead whale skin marked with grid lines and caulked into the working area of the flow tank. (B) Flow tank. (C) Close-up of mud on skin under water. (D) Adobe Acrobat Professional area measurement tool was used to analyze JPEGs to determine the proportions of mud remaining on test squares throughout each test.

The tests were conducted at $0.83 \mathrm{~m} / \mathrm{s}(3 \mathrm{~km} / \mathrm{h})$ and $1.67 \mathrm{~m} / \mathrm{s}(6 \mathrm{~km} / \mathrm{h})$ to correspond to mean and fast bowhead swim speeds, respectively (Zeh et al. 1993). This corresponds well to tag data on feeding bowhead whales (Simon et al. 2009). Simon et al. (2009) conclude that feeding bowhead whales swim at an average speed of less than $1 \mathrm{~m} / \mathrm{s}$ at depth. Most tests were conducted with 4.9 cc of Beaufort Sea mud spread over six predefined squares within the grid drawn on the skin (Fig. 2C). Two tests were run at varying mud thicknesses $(0.6 \mathrm{cc}$ and $14.8 \mathrm{cc})$ to test how relative mud thickness affects flushing. Although mud thickness was essentially arbitrary, we used standard culinary measuring spoons to make the relative amounts consistent and easy to measure (i.e., $4.9 \mathrm{cc}$ equals 1 teaspoon, $0.6 \mathrm{cc}$ equals $1 / 8$ teaspoon, and 14.8 cc equals 1 tablespoon).

All tests were recorded with a Sony DVCAM (Sony Corp., Tokyo, Japan) minivideo recorder set to record continuously for the first $5 \mathrm{~min}$ of each test and then for $2 \mathrm{~s}$ at $5 \mathrm{~min}$ intervals thereafter. After completion of the tests, the Sony DVCAM video clips were imported into Windows Movie Maker software and we converted eight clips per test into JPEG files for analysis. The eight clips were chosen based on the time increments that we wanted to compare: $0 \mathrm{~min}, 1 \mathrm{~min}, 5 \mathrm{~min}, 10 \mathrm{~min}, 20$ min, $30 \mathrm{~min}, 1 \mathrm{~h}$, and $2 \mathrm{~h}$. Those JPEGs were then converted into PDFs in Adobe Acrobat 8 Professional, enabling us to use the area measurement tool to estimate proportions of mud remaining for each time interval (Fig. 2D). 


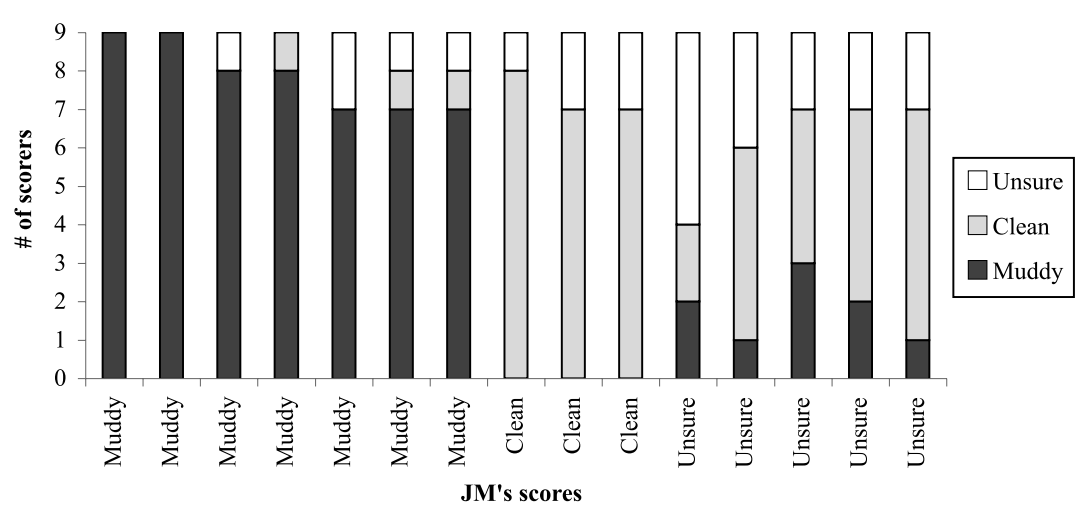

Figure 3. Results of the scoring test given to bowhead whale experts compared to JM's scores on 15 images.

\section{Analyses}

Whale sighting locations for all photographs that were scored for this study were plotted in ArcGIS 9.2 in order to visualize patterns that may emerge when comparing year-to-year locations of feeding and nonfeeding whales.

For all data comparisons, we first transformed the data (normalized the proportions) by using an empirical logistic transform (Cox and Snell 1989). The normalized data were then compared independently using pairwise $t$-tests (two-tailed) to test for significant differences.

\section{RESULTS}

\section{Testing of Scoring System}

Julie Mocklin (JM) scored all of the photographs for this study, so we tested the scoring system by comparing others' scores to JM. Initial development and testing of the system consisted of having four biologists at NMML evaluate a selection of bowhead whale images (Mocklin 2009). The sum of their definitive "yes" and "no" decisions (when $>70 \%$ sure) was divided by JM's sum. This showed an $88 \%$ agreement with JM.

Additionally, a simplified test was given to bowhead experts (Inupiat whalers and biologists specializing in bowhead research). Agreement was also very good between bowhead experts and JM when comparing images that JM scored as "muddy" or "clean" (Fig. 3). Scores were much more variable for the photos that JM had scored as "unsure." After removing images that JM was uncertain about, there was $100 \%$ agreement for images that JM scored as "clean" and $93.8 \%$ agreement on images JM scored as "muddy." These results support JM's methods of scoring and assignment of feeding categories as presented in this study.

\section{Testing of Mud Flush Rates}

The first (and longest) test conducted in the flow tank consisted of $4.9 \mathrm{cc}$ of mud at medium speed. After $9 \mathrm{~h}$, there was still a detectable amount of mud on the skin (approximately one-quarter of one of the six squares); however, this amount of mud 
would probably not be detectable in an aerial photograph of a whale. After this test, we decided that it was necessary to limit the test run time to $2 \mathrm{~h}$ and conduct tests at fast flow rates so that more change could be detected within reasonable time spans. Typically, mud flushed at a faster rate during the first minute of a test as a result of bringing the flow tank up to full speed. After the tank flow stabilized from this initial surge, then the mud flushed much more slowly throughout the remaining $2 \mathrm{~h}$. Generally within $2 \mathrm{~h}$ at fast speed $(6 \mathrm{~km} / \mathrm{h}), 4.9 \mathrm{cc}$ of mud was almost all gone (three replicates) whereas the same amount of mud exposed to medium speed $(3 \mathrm{~km} / \mathrm{h})$ water flow (two replicates) was almost all still present.

In order to apply $0.6 \mathrm{cc}$ of mud over the full area equally, it was necessary to spread it in a very thin layer over the six squares. It became evident that a thin layer of mud was more persistent than thick mud. The test of $14.8 \mathrm{cc}$ of mud dissipated very quickly, probably within $10 \mathrm{~min}$, but it made the water so murky that it was hard to see exactly when it became totally clean. Irregularities in the mud surface caused higher ablation rates. In all tests, the mud flushed by breaking off in chunks and rolling over the back of the skin as it peeled away. Test results were adjusted in an attempt to minimize the impacts of irregularities in mud applications as well as mud dissipating as a result of the water flow reaching full speed; this was done by excluding the first minute of each test and using $t=1$ as the baseline for subsequent proportional observations.

Based on these tests, it seems reasonable to conclude that mud stuck to a fast $(6 \mathrm{~km} / \mathrm{h})$ swimming bowhead would be flushed from the whale within a couple of hours. For a whale swimming at roughly $3 \mathrm{~km} / \mathrm{h}$ (a typical speed for a bowhead), a coating of mud might be present for nearly half a day but probably less than one full day. A whale swimming at consistently slow speeds might retain mud on its body for over a day. Mud flush rates will vary depending on the thickness of the mud entrained on the whale and also the location on the body. One would expect mud to flush more quickly off the hind-third of the body, where propulsion is generated by undulating flukes, than the front two-thirds of the body (see Pierre and Louis 1998).

In order to ground truth the flow tank tests, queries of the bowhead photographic database were run to see if there were examples of individual whales that were captured photographically at different times and with varying feeding designations. Due to aerial survey protocols to minimize recaptures, it is difficult to find many examples of the same whale photographed within $1 \mathrm{~d}$. Out of a sample of 3,649 images, there were 470 within-day matches; however, most of these were taken very close in time. This sample size dwindled to 34 when the query was limited to images taken $>15$ min apart. Furthermore, when we only queried matches that were taken more than $2 \mathrm{~h}$ apart (a time scale consistent with the flow tank tests), there were only eight matches remaining. The longest time that mud persisted on a whale within these sample sets was just over $4 \mathrm{~h}$. There were no examples of a muddied whale that turned clean in subsequent photos. Note that the likelihood of recognizing whales in subsequent photographs is reduced if the mud has changed substantially.

\section{Interannual Variation of Epibentbic Feeding}

Greater than half of all photographs analyzed showed evidence of epibenthic feeding, but there were clear interannual variations in the data (Fig. 4, 5). Combining all sample sets yielded a total of $64 \%$ definitively muddy whales (this combines the "mud" and "mud and open mouth" categories and is conservative because many 
$\square$ Mud $\square$ Mud and open mouth $\square$ Open mouth $\square$ No evidence of feeding

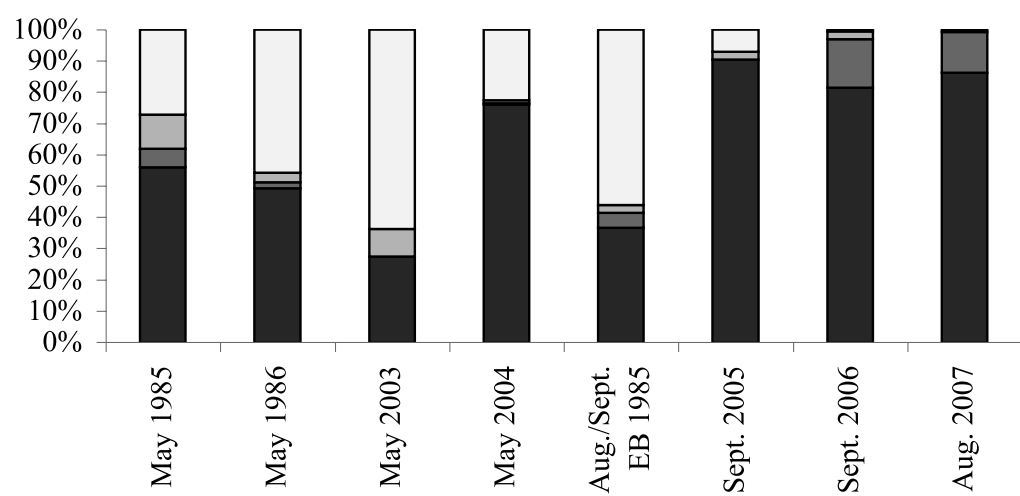

Figure 4. Percentages of photographed bowhead whales that were assigned definitive feeding categories. All samples are from the Barrow, Alaska area, except August/September EB, which denotes the eastern Beaufort Sea.

images that were not obviously muddy were excluded from this summary). Proportions of muddy whales differed significantly among each May sample off of Barrow (Table 2). When all four of these sample sets from May were combined, 55.4\% showed clear evidence of epibenthic feeding, 39.2\% showed no evidence of feeding, and $5.4 \%$ had open mouths. May 2003 stood out as having the smallest percentage of feeding whales, and 2004 had the largest percentage of feeding whales (27\% and $76 \%$, respectively).

The sum of the samples from Barrow in May was highly significantly less muddy than the sum of samples from late summer near Barrow $(P<0.001)$. When the three sample sets in late summer off of Barrow were combined, $97 \%$ were muddy, $1 \%$ showed no evidence of feeding, and $2 \%$ had open mouths. The percent of muddy

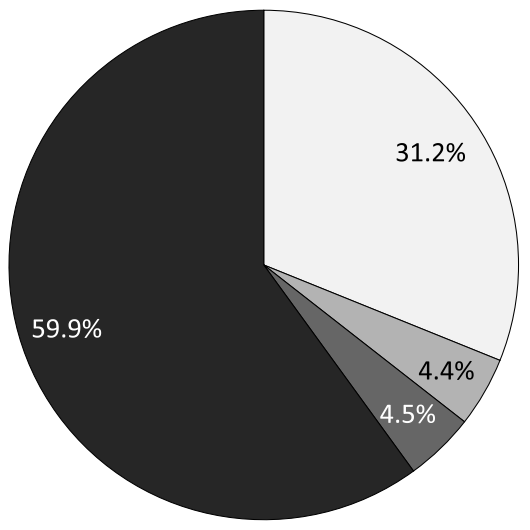

$\square$ No Evidence of feeding
$\square$ Open mouth
$\square$ Mud and open mouth
$\square$ Mud

Figure 5. Percentages of feeding designations from bowhead whale photographic evaluations of all sample sets combined. 
Table 2. Results from pairwise $t$-tests for significant differences between the proportions of muddy bowhead whales among sample sets, after performing empirical logistic transform. Data are from the Barrow, Alaska area in May unless otherwise noted.

\begin{tabular}{lccccc}
\hline \hline & 1985 & 1986 & 2003 & 2004 & All Mays \\
\hline 1985 & - & 0.09 & $<0.001$ & 0.002 & 0.046 \\
1986 & & - & $<0.001$ & $<0.001$ & 0.46 \\
2003 & & & - & $<0.001$ & $<0.001$ \\
2004 & 0.001 & & & - & $<0.001$ \\
$1985 \mathrm{~EB}^{\mathrm{a}}$ & & & & 0.01 \\
\hline
\end{tabular}

${ }^{a} 1985$ EB represents the sample from August/September in the eastern Beaufort Sea and is included here to show how it compared to the western Beaufort Sea within the same year as well as compared to the combined May samples off Barrow.

whales in late summer in the eastern Beaufort Sea was significantly $(P<0.001)$ different from the percent of muddy whales off Barrow in late summer (Table 3).

\section{Spatial Variation of Epibenthic Feeding}

No obvious pattern emerges in the series of ArcGIS maps (Fig. 6, 7) to suggest that feeding whales are consistently located separately from nonfeeding whales. However, there is a limit to determining feeding locations through photographic analysis since mud can be so persistent on bowhead whale skin. Therefore, feeding whale locations were not analyzed with respect to bathymetry. It is clear from this analysis, however, that the Barrow area is an important and commonly used feeding area during migrations both in the spring ( $55 \%$ of the sample were muddy) and autumn (97\% of the sample) and in agreement with published records, which suggest that whales prefer shelf waters off Barrow (Moore and Reeves 1993, Moore 2000, Moore et al. 2000).

\section{Age Class and Epibenthic Feeding}

For most of the sample sets evaluated, there were no differences between the proportions of muddy juveniles to muddy adults. In May of 1986 and when all four May sample sets off Barrow were combined, there was a significant difference, with muddy adults being more common (Table 4).

Table 3. Results from pairwise $t$-tests for significant differences between the proportions of muddy bowhead whales among data from late summer sample sets, after performing empirical logistic transform. Data are from the Barrow, Alaska area unless otherwise noted.

\begin{tabular}{lcccc}
\hline \hline & 2005 & 2006 & 2007 & All Barrow \\
\hline 2005 & - & 0.06 & 0.01 & \\
2006 & & - & 0.18 & \\
2007 & & & - & $<0.001$ \\
$1985 \mathrm{~EB}^{\mathrm{a}}$ & & & & \\
\hline
\end{tabular}

${ }^{a} 1985$ EB represents the sample from August/September in the eastern Beaufort Sea. 


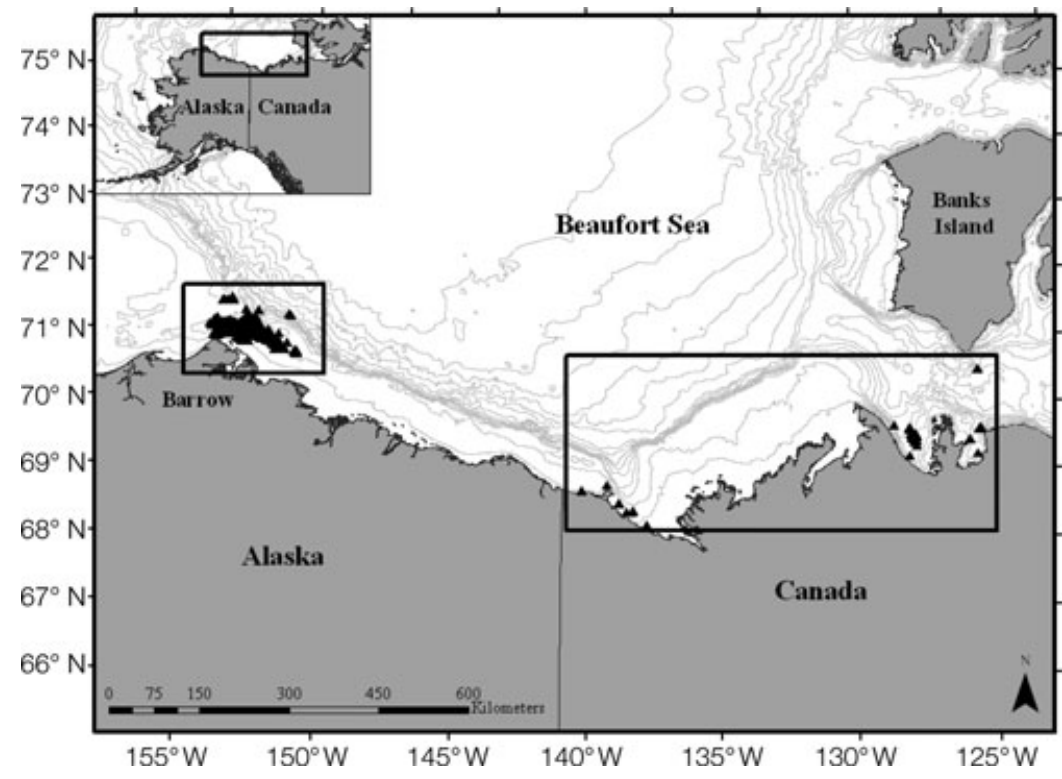

Figure 6. Overview of locations of photographed whales examined in this study of feeding bowheads. Boxes depict the general area where photographs were taken. A scarcity of sighting locations in the eastern Beaufort Sea is a reflection of sample effort and is not considered representative of whale distribution.

\section{DisCUSSION}

Our study of aerial photographs of bowhead whales has proven to be an excellent tool for remotely assessing epibenthic feeding behavior. These results indicate that this feeding strategy is quite prevalent, more so than the literature would suggest. This is largely because most aerial observations of feeding whales have been in the eastern Beaufort Sea, the area long recognized as the main feeding ground for the BCB bowheads (Lowry 1993). In the eastern Beaufort Sea, it appears that water-column feeding is the most common feeding strategy. Würsig and Clark (1993) go so far as

Table 4. Proportions of muddy juveniles and adult bowhead whales (from the Barrow, Alaska area unless otherwise noted). The $P$-value results from a $t$-test for significant differences between the proportion of muddy juveniles and adults within sample sets, after performing empirical logistic transform.

\begin{tabular}{lcccc}
\hline \hline Year & Juveniles & Adults & Total & $P$ \\
\hline May 1985 & 0.64 & 0.62 & 0.63 & 0.78 \\
May 1986 & 0.38 & 0.67 & 0.54 & 0.0005 \\
May 2003 & 0.25 & 0.28 & 0.27 & 0.61 \\
May 2004 & 0.84 & 0.74 & 0.76 & 0.12 \\
May all years & 0.50 & 0.60 & 0.57 & 0.004 \\
1985 E. Beaufort Sea & 0.52 & 0.36 & 0.41 & 0.17 \\
\hline
\end{tabular}



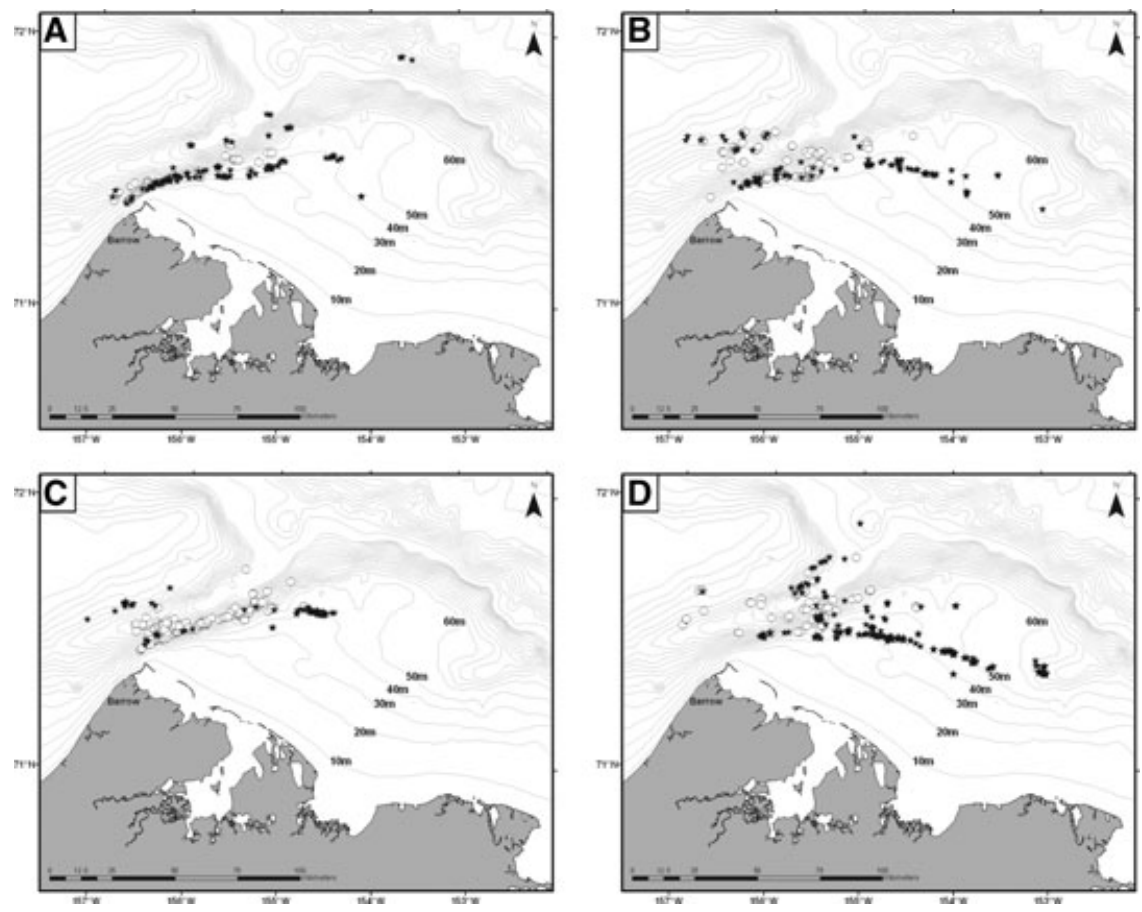

Figure 7. Locations of photographed whales examined in this study of feeding bowheads in May, off Barrow, Alaska. Stars indicate evidence of epibenthic feeding; circles show no evidence of feeding: (A) 1985, (B) 1986, (C) 2003, (D) 2004. Note that the southern boundary of the whale migration through this area is limited by shorefast ice in the spring.

to state that water-column feeding in that region is "undoubtedly by far the most common feeding mode."

It was, however, in the eastern Beaufort Sea where Würsig et al. (1985) witnessed and presented the first published observations of muddy bowhead whales. They saw whales surfacing with mud streaming out of their mouths in quantities they describe as "too great to have been picked up incidentally while feeding in the water column near the bottom." The authors suggest that at times the whales were actually feeding directly on the seafloor. However, Würsig and Clark (1993) explained that bowheads were most likely skimming clouds of prey just above the bottom substrate (i.e., epibenthic prey) and not targeting infaunal prey. That bowheads feed near the bottom is supported by analysis of stomach contents (Lowry 1993). Additionally, in 1989 near Point Lonely (approximately $135 \mathrm{~km}$ east of Barrow and within the study area), scientists made seven dives in the vicinity of feeding whales that were seen with mud streaming out of their mouths (Wartzok et al. 1990). Benthic cores contained little fauna, but plankton net tows $10-100 \mathrm{~cm}$ above the bottom yielded copepods. The scientists reported that the suspended sediments within $1 \mathrm{~m}$ of the sea floor were so thick that visibility was very poor, and they concluded that the bowheads must have been feeding near the bottom (rather than in it), and that feeding in this sediment-laden layer caused the mud to be visible as plumes streaming out of 
the mouth. They also noted that there was no evidence of bottom disturbance by bowheads in that area. However, the idea of bowheads creating pits in the substrate while feeding has been hypothesized in the past (Hein and Syvitski 1989) as it has for right whales (Stone et al. 1990).

Like all large whales, bowheads feed where prey is most dense, and it is well known that bowheads are capable of foraging at significant depths (Krutzikowsky and Mate 2000, Laidre et al. 2007). Tagged bowhead whales in the Bering Sea dove to depths near the seafloor in $99 \%$ of all $6 \mathrm{~h}$ recording intervals. ${ }^{2}$ Feeding efficiency may be elevated by seeking out highly caloric prey in dense masses. It is well known that copepods and euphausiids routinely make diel vertical migrations in the water column such that they are located deeper during daylight hours as a predator avoidance strategy (Fortier et al. 2001, Hays 2003). Additionally, bigger zooplankton with higher lipid reserves are more likely to remain in deeper water (Baumgartner et al. 2003, Hays 2003). It seems that whales utilizing both the watercolumn feeding strategy and those feeding epibenthically are actually targeting the same prey species. Baumgartner and Mate (2003) found that right whales targeted copepods that aggregated just above the bottom mix layer, regardless of the depth at which the bottom mix layer occurred.

This study reveals that the epibenthic feeding strategy is a common feeding behavior in the Barrow area in both the spring and autumn. Models developed by Berline et al. (2008) indicated that peak euphausiid abundance should occur in the spring and autumn in the Barrow area, coinciding with bowhead migratory timing. Oceanographic conditions that contribute to bowhead prey assemblages, as well as bowhead whale occurrence and behavior, were investigated near Barrow in late summer 2005 and 2006 (Ashjian et al. 2010, Moore et al. 2010). The timing and extent of wind forcing near Barrow appears important to establishing a "krill trap," which whales use for efficient foraging (Ashjian et al. 2010).

Results from echosounder surveys in the eastern Alaska Beaufort Sea in September 1985 and 1986 showed that zooplankton biomass in nearshore areas was greatest near the bottom (depth range 10-30 m), and in the inner and outer shelf zones, biomass was greatest in depths between $10 \mathrm{~m}$ and $40 \mathrm{~m}$ (Griffiths et al. 1987). Griffiths et al. (1987) also found that average zooplankton biomass was higher in the nearshore and inner shelf areas (shoreward of the $50 \mathrm{~m}$ contour) compared to the outer shelf area (seaward of the $50 \mathrm{~m}$ contour), with copepods being the dominant zooplankton in the nearshore areas. From analysis of stomach contents of whales landed at Barrow, it appears that bowheads are primarily targeting euphausiids off Barrow, especially in late summer (Lowry et al. 2004, Moore et al. 2010). Griffiths et al. (1987) also found a higher biomass of euphausiids in the western compared to eastern Alaska Beaufort Sea.

Würsig and Clark (1993) postulated that feeding epibenthically may be a strategy that is employed most often, and possibly exclusively, by juvenile bowhead whales. There has been some evidence in stomach content analyses that juveniles may target bottom prey more than adults, but the difference was not significant (Lowry 1993, Lowry et al. 2004). Budge et al. (2008) found a statistically significant correlation between body length and fatty acid composition in the blubber suggesting that diet varies with age. However, some of the small whales in their sample set may have still been nursing, which could explain some of the difference. Interestingly,

\footnotetext{
${ }^{2}$ Personal communication from Lori Quakenbush, Alaska Department of Fish and Game, Arctic Marine Mammal Program, 1300 College Road, Fairbanks, AK 99701, May 2010.
} 
our research showed that for most of the years examined (including the eastern Beaufort Sea sample) there was no statistical difference between the proportion of muddy juveniles to the proportion of muddy adults. However, in the only two sample sets that showed a significant difference, it was adults that made up the largest proportion of epibenthic feeders, not the juveniles. It is worth noting that the bowhead migrations are segregated such that younger animals lead the migration in spring and large, older adults are more prevalent at the end of the migration (Angliss et al. 1995). The autumn migration reverses the age segregation with older whales preceding the younger whales. Therefore, it is important when comparing age classes that a representative cross-section of the population is sampled. We used photographs from the entire month of May for all of the analyses pertaining to age-related feeding behavior. May represents the mid-portion of the spring migration and therefore is a relatively equal mix of juveniles and adults (Angliss et al. 1995).

Our results correspond well with the evidence that bowheads feed more during the autumn than spring migrations (e.g., Lowry and Frost 1984). There was photographic evidence that $99 \%$ of all whales off Barrow in late summer (August and September of 2005, 2006, and 2007) were feeding, of which 97\% showed evidence of epibenthic feeding. In spring off Barrow (May of 1985, 1986, 2003, and 2004), 61\% of whales were feeding, of which $55 \%$ were feeding epibenthically. These percents are higher than has been determined from stomach content analyses for both the summer and autumn. Lowry et al. (2004) found that $76 \%$ of whales killed in the autumn at Barrow had been feeding, and 34\% of whales killed in spring off Barrow had food in their stomachs. However, Lowry et al. (2004) explained that stomach content analyses are likely to underestimate feeding. For example, if too much time lapses before a stomach can be examined, then the food may be well digested before contents can be analyzed. Also, some samples are in such poor condition that evaluations of prey are severely hampered.

The utility of analyzing photographic data for evidence of feeding bowhead whales in the Barrow area has proven quite successful. In addition, the method of scoring created for this study has been shown to be robust. The feeding categories developed here were successfully taught to other biologists with reasonable repeatability and agreement in the results. It is particularly noteworthy that bowhead biologists and whalers displayed high levels of agreement with the assessments of mud on the whales' skin. Although there is a limitation to detecting the precise location where feeding occurred, these data can be used to show generalized areas where feeding was underway. There is photographic proof that mud can persist for over $4 \mathrm{~h}$ on an individual bowhead. We also conducted a laboratory test simulating near realworld conditions of flush rates of Beaufort Sea mud, collected from the Barrow area, off of bowhead whale skin in saltwater at flow speeds corresponding to bowhead whale swim speeds. The evidence from the flow tank tests suggests that mud in the Barrow area can persist on bowhead skin for up to $9 \mathrm{~h}$, if not more. If this test adequately represented a swimming whale, then that particular individual could have become muddied as much as $27 \mathrm{~km}$ away (swimming at an average speed of $3 \mathrm{~km} / \mathrm{h}$ ). However, it is expected that the controlled nature of the flow tank tests resulted in an overestimation of mud persistence because a swimming whale likely encounters more variable and complex dynamics (e.g., wave action when surfacing to breathe, differing mud amounts, and swim speeds throughout a day) than a lab test could simulate. Also, the mud used in this test may have been particularly viscous; sandier mud would not persist as long, and sand or gravel substrates would probably not adhere to a whale's skin at all. 
It would be beneficial for understanding bowhead feeding dynamics if a timedepth-recorder tag was attached on a bowhead feeding in the Barrow area. This could document the vertical location of the whale relative to the sea floor. Also, pitch and roll data could elucidate how whales are oriented when feeding near the sea floor. It is likely that bowheads turn upside down when feeding just above the substrate, which would explain the streaks of mud across their dorsal surfaces, but this remains unverified. The anatomy of a bowhead whale makes it such that a whale touching the seafloor with its ventral surface would have one or more meters between its mouth and the epibenthic fauna below, whereas an upside-down whale would have its mouth only tens of centimeters from the seafloor. Furthermore, it is possible that the deep cuts on most bowheads' backs, used in aerial photographs to identify individual whales, may be caused by rubbing against sharp objects on the seafloor. A more detailed understanding of the concentrations and behavior of zooplankton in the Barrow area is needed as well. Understanding the behavior of the whales' prey will be very helpful in understanding how whales have adapted to feed on the prey.

This research, examining aerial photographs of bowhead whales, highlights the need to continue collecting photographs of this population as an effective means to learn and monitor many facets of bowhead ecology. Indeed, collecting photographs is crucial in order to properly assess feeding bowhead whales. Feeding behavior, including mud on whales, may not be sufficiently recognized during regular aerial transect surveys. Photographic analysis has documented that epibenthic feeding is an important strategy for bowheads. Over $64 \%$ of the aerial photographs showed whales with distinct evidence of mud, and many more images had equivocal evidence not used in these analyses.

This study demonstrates two key facets of bowhead whale ecology that should be considered when evaluating the risk of oil spills to this species. First, evidence of extensive epibenthic feeding indicates that these whales could be exposed to hydrocarbons entrained in the sediment following an oil spill. Second, the study shows that the area near Barrow, which was previously believed to be only a migratory corridor, is actually an important feeding area for this species when certain oceanographic conditions occur. This importance may be elevated as bowhead abundance increases (George et al. 2004) and there is more reoccupation of the western Beaufort Sea and the Chukchi Sea in the summer, an area more commonly used by bowheads prior to commercial whaling (Bockstoce et al. 2005, Moore et al. 2010). Future studies will be needed to determine other areas where epibenthic feeding is the predominant foraging strategy, and more research is critical to better understanding the full potential for impact of hydrocarbons on feeding bowhead whales.

\section{ACKNOWLEDGMENTS}

This research would not have been possible without support from the National Marine Mammal Laboratory, and funding from the Minerals Management Service, especially Chuck Monnett. Photographs were collected under Scientific Research Permits 580, 670, 791, 7821438, and 782-1791, and the whale tissue sample was provided under Permit 797; all of these permits were under the provisions of the U.S. Marine Mammal Protection Act and Endangered Species Act. Scientists from the Alaska Fisheries Science Center, NOAA, donated Beaufort Sea mud, and Kim Rand was especially helpful. We are grateful to all the biologists and Inupiat hunters that took part in the testing process of the scoring system used for this study (in alphabetical order): Harry Brower, Lewis Brower, Janet Clarke, Craig George, Bill Koski, Christy Sims, Robert Suydam, Katie Sweeney, and Janice Waite. Bill Koski at 
LGL gave feedback at various points of this research endeavor, and he provided all the whale lengths. The North Slope Borough and Barrow Whaling Captains Association have been gracious with their time and support of this study. Thanks to Jim Slavas, Emily Carrington, and Noah Lawrence-Slavas for providing helpful advice on designing the flow tank test, which was conducted at the University of Washington's laboratory at Friday Harbor, Washington. Noah was invaluable in designing and implementing the experiment successfully. Much appreciation goes to Ken Raedeke and Rod Hobbs for advice on earlier versions of this work. We thank Kim Shelden, Dee Allen, and two anonymous reviewers for providing helpful reviews of this manuscript. Reference to trade names does not imply endorsement by the National Marine Fisheries Service, NOAA.

\section{Literature Cited}

Angliss, R. P., D. J. Rugh, D. E. Withrow and R. C. Hobbs. 1995. Evaluations of aerial photogrammetric length measurements of the Bering-Chukchi-Beaufort seas stock of bowhead whales (Balaena mysticetus). Report of the International Whaling Commission 45:313-324.

Ashjian, C. J., S. R. Braund, R. G. Campbell, et al. 2010. Climate variability, oceanography, bowhead whale distribution, and Iñupiat subsistence whaling near Barrow, AK. Arctic 63:179-194.

Baumgartner, M. F., T. V. N. Cole, R. G. Campbell, G. J. Teegarden and E. G. Durbin. 2003. Associations between North Atlantic right whales and their prey, Calanus finmarchicus, over diel and tidal time scales. Marine Ecology Progress Series 264:155-166.

Baumgartner, M. F., and B. R. Mate. 2003. Summertime foraging ecology of North Atlantic right whales. Marine Ecology Progress Series 264:123-135.

Berline, L., Y. H. Spitz, C. J. Ashjian, R. G. Campbell, W. Maslowski and S. E. Moore. 2008. Euphausiid transport in the Western Arctic Ocean. Marine Ecology Progress Series 360:163-178.

Bockstoce, J. R., D. B. Botkin, A. Philp, B. W. Collins and J. C. George. 2005. The geographic distribution of bowhead whales in the Bering, Chukchi and Beaufort Seas: Evidence from whaleship records, 1849-1914. Marine Fisheries Review 67:1-43.

Budge, S. M, A. M. Springer, S. J. Iverson, G. Sheffield and C. Rosa. 2008. Blubber fatty acid composition of bowhead whales, Balaena mysticetus: Implications for diet assessment and ecosystem monitoring. Journal of Experimental Marine Biology and Ecology 359:4046.

Carroll, G. M., J. C. George, L. F. Lowry and K. O. Coyle. 1987. Bowhead whale (Balaena mysticetus) feeding near Point Barrow, Alaska, during the 1985 spring migration. Arctic 40:105-110.

Cox, D. R., and E. J. Snell. 1989. Analysis of binary data. 2nd edition. Monographs on statistics and applied probability. Volume 32. Chapman and Hall, London, U.K.

Da Silva, C. Q., J. Zeh, D. Madigan, et al. 2000. Capture-recapture estimation of bowhead whale population size using photo-identification data. Journal of Cetacean Research and Management 2:45-61.

Fortier, M., L. Fortier, H. Hattori, H. Saito and L. Legendre. 2001. Visual predators and the diel vertical migration of copepods under Arctic sea ice during the midnight sun. Journal of Plankton Research 23:1263-1278.

George, J. C., J. Zeh, R. Suydam and C. Clark. 2004. Abundance and population trend (1978-2001) of western Arctic bowhead whales surveyed near Barrow, AK. 2004. Marine Mammal Science 20:775-773.

Griffiths, W. B., D. H. Thomson and G. E. Johnson. 1987. Zooplankton and hydroacoustics. Pages 135-256 in W. J. Richardson, ed. Importance of the eastern Alaskan Beaufort Sea to feeding bowhead whales, 1985-86. Report by LGL ecological research associates Inc. to U.S. Minerals Management Service. NTIS No. PB 88 150271/AS. 
Hays, G. C. 2003. A review of the adaptive significance and ecosystem consequences of zooplankton diel vertical migrations. Hydrobiologia 503:163-170.

Hazard, K. W., and L. F. Lowry. 1984. Benthic prey in a bowhead whale from the northern Bering Sea. Arctic 37:166-168.

Hein, F. J., and J. P. M. Syvitski.1989. Sea floor gouges and pits in deep fjords, Baffin Island: Possible mammalian feeding traces. Geo-Marine Letters 9:91-94.

Koski, W. R., R. A Davis, G. W. Miller and D. E. Withrow. 1992. Growth rates of bowhead whales as determined from low-level aerial photogrammetry. Report of the International Whaling Commission 42:491-499.

Koski, W. R., R. A. Davis, G. W. Miller and D. E. Withrow. 1993. Reproduction. Pages 239-274 in J. J. Burns, J. J. Montague and C. J. Cowles, eds. The bowhead whale. Special Publication Number 2, The Society for Marine Mammalogy.

Koski, W. R., J. Zeh, J. Mocklin, A. R. Davis, D. J. Rugh, J. C. George and R. Suydam. 2010. Abundance of Bering-Chukchi-Beaufort bowhead whales (Balaena mysticetus) in 2004 estimated from photo-identification data. Journal of Cetacean Research and Management 11:89-99.

Krutzikowsky, G. K., and B. R. Mate. 2000. Dive and surfacing characteristics of bowhead whales (Balaena mysticetus) in the Beaufort and Chukchi seas. Canadian Journal of Zoology 78:1182-1198.

Laidre, K. L., M. P. Heide-Jørgensen and T. G. Nielsen. 2007. Role of the bowhead whale as a predator in West Greenland. Marine Ecology Progress Series 346:285-297.

Landino, S. W., S. D. Treacy, S. A. Zerwick and J. B. Dunlap. 1994. A large aggregation of bowhead whales (Balaena mysticetus) feeding near Point Barrow, Alaska, in late October 1992. Arctic 47:232-235.

Ljungblad, D. K., S. E. Moore and J. T. Clarke. 1986. Assessment of bowhead whale (Balaena mysticetus) feeding patterns in the Alaskan Beaufort and northeastern Chukchi Seas via aerial surveys, fall 1979-84. Report of the International Whaling Commission 36:265272.

Lowry, L. F. 1993. Foods and feeding ecology. Pages 201-238 in J. J. Burns, J. J. Montague and C. J. Cowles, eds. The bowhead whale. Special Publication Number 2, The Society for Marine Mammalogy.

Lowry, L. F., and K. J. Frost. 1984. Foods and feeding of bowhead whales in western and northern Alaska. The Scientific Reports of the Whales Research Institute, Tokyo 35:116.

Lowry, L. F., G. Sheffield and J. C. George. 2004. Bowhead whale feeding in the Alaskan Beaufort Sea, based on stomach contents analyses. Journal of Cetacean Research and Management 6:215-224.

Miller, G. W., R. A. Davis, W. R. Koski, M. J. Crone, D. J. Rugh, D. E. Withrow and M. Fraker. 1992. Calving intervals of bowhead whales-An analysis of photographic data. Report of the International Whaling Commission 42:501-506.

Mocklin, J. A. 2009. Evidence of bowhead whale feeding behavior from aerial photography. AFSC Processed Report 2009-06, Alaska Fisheries Science Center, National Marine Fisheries Service, NOAA, 7600 Sand Point Way NE, Seattle WA. 118 pp.

Moore, S. E. 2000. Variability of cetacean distribution and habitat selection in the Alaskan Arctic, autumn 1982-91. Arctic 53:448-460.

Moore, S. E., and R. R. Reeves. 1993. Distribution and movement. Pages 313-386 in J. J. Burns, J. J. Montague and C. J. Cowles, eds. The bowhead whale. Special Publication Number 2, The Society for Marine Mammalogy.

Moore, S. E., D. P. DeMaster and P. K. Dayton. 2000. Cetacean habitat selection in the Alaskan Arctic during summer and autumn. Arctic 53:432-447.

Moore, S. E., J. C. George, G. Sheffield, J. Bacon and C. J. Ashjian. 2010. Bowhead whale distribution and feeding near Barrow, Alaska in late summer 2005-06. Arctic 63: $195-205$. 
Pierre, L., and L. Louis. 1998. Dimensional analysis in ecology. Pages 97-129 in P. Legendre and L. Legendre, eds. Developments in environmental modeling. 2nd English edition. Elsevier, Amsterdam, The Netherlands.

Rugh, D. 1990. Bowhead whales reidentified through aerial photography near Point Barrow, Alaska. Pages 289-294 in P. S. Hammond, S. A. Mizroch and G. P. Donovan, eds. Individual recognition of cetaceans: Use of photo-identification and other techniques to estimate population parameters. International Whaling Commission (Special Issue 12), Cambridge.

Rugh, D. J., G. W. Miller, D. E. Withrow and W. R. Koski. 1992. Bowhead whale calving intervals established through photographic reidentifications. Journal of Mammalogy 73:487-490.

Schweder, T. 2003. Abundance estimation from multiple photo surveys: Confidence distributions and reduced likelihoods for bowhead whales off Alaska. Biometrics 59:974-983.

Simon, M., M. Johnson, P. Tyack and P. Madsen. 2009. Behaviour and kinematics of continuous ram filtration in bowhead whales (Balaena mysticetus). Proceedings of the Royal Society B-Biological Sciences 276:3819-3828.

Stone, G., D. LoValvo, S. Kraus and M. Crone. 1990. Low-cost ROV used to study right whale ecology in the Bay of Fundy. Available from Marine Technology Society, $1825 \mathrm{~K}$ Street N.W., Suite 218, Washington, DC 20006.

Wartzok, D., W. A. Watkins, B. Würsig, J. Guerro and J. Schoenherr. 1990. Movements and behaviors of bowhead whales. Final Report submitted to Amoco Production Company. Available from Purdue University, Fort Wayne, IN 46805-1499.

Würsig, B., and C. Clark. 1993. Behavior. Pages 157-199 in J. J. Burns, J. J. Montague and C. J. Cowles, eds. The bowhead whale. Special Publication Number 2, The Society for Marine Mammalogy.

Würsig, B., E. M. Dorsey, M. A. Fraker, R. S. Payne and W. J. Richardson. 1985. Behavior of bowhead whales, Balaena mysticetus, summering in the Beaufort Sea: A description. Fishery Bulletin 83:357-377.

Würsig, B., E. M. Dorsey, W. J. Richardson and R. S. Wells. 1989. Feeding, aerial and play behavior of bowhead whales, Balaena mysticetus, summering in the Beaufort Sea. Aquatic Mammals 15:27-37.

Zeh, J. E., C. W. Clark, J. C. George, D. Withrow, G. M. Carroll and W. R. Koski. 1993. Current population size and dynamics. Pages 409-489 in J. J. Burns, J. J. Montague and C. J. Cowles, eds. The bowhead whale. Special Publication Number 2, The Society for Marine Mammalogy.

Zeh, J., D. Poole, G. Miller, W. Koski, L. Baraff and D. Rugh. 2002. Survival of bowhead whales, Balaena mysticetus, estimated from 1981-1998 photoidentification data. Biometrics 58:832-840. 